\title{
Inactivation of high concentration of pathogens in land-applied food industry sludge
}

\author{
JM Méndez-Contreras*, J Atenodoro, FA Champión, NA Vallejo-Cantú and A Alvarado-Lassman \\ *Instituto Tecnológico de Orizaba (ITO), Av. Instituto Tecnológico, Col. Emiliano Zapata 94320, Orizaba, Ver. Mexico
}

\begin{abstract}
In Mexico, as in other developing countries, the most important pollution and management problems of food-processing sludge are the high levels of pathogen microorganisms within the sludge and the lack of sites for its disposal. The aims of this study were to evaluate the effect of calcium oxide in the inactivation of pathogenic microorganisms and the subsequent use of the resulting product in an agricultural application at various agronomic rates. Stabilisation tests were done in a hermetically closed fibreglass reactor with $1.5 \ell$ capacity, using physicochemical sludge with concentrations of 4,8 and $12 \%$ of total solids (TS) and contact times of 30, 60 and $90 \mathrm{~min}$. At the end of each treatment, the raw and treated sludge quality was evaluated. Recommended doses for Class A biosolids production were 20,10 and $8 \% \mathrm{~m} / \mathrm{m}$ of $\mathrm{CaO}$ for 4,8 and $12 \%$ of TS respectively with a minimum contact time of $90 \mathrm{~min}$. The land-application test was done using sludge with $8 \%$ TS treated with a quicklime dose of $10 \% \mathrm{~m} / \mathrm{m}$. Nitrogen-based Agronomic Rates (AR) of $0,1,5,10$ and 15 were evaluated in the cultivation and production of chayote (Sechium edule). The results with 5 AR showed an estimated total production of $70 \mathrm{~kg}$ of the vegetable species over a period of $90 \mathrm{~d}$, which is higher than that reported for the same crop grown without biosolids application.
\end{abstract}

Keywords: land application, quicklime $(\mathrm{CaO})$ treated biosolids, Sechium edule development, vertisols

\section{Introduction}

Currently Mexico generates approximately 12000000 t/a of sludge containing high levels of organic matter, pathogen microorganisms and parasites (Ortega, 2003). The concentrations of microorganisms (faecal coliforms $6.9 \times 10^{9} \mathrm{MPN} / \mathrm{g}$ TS and Salmonella spp. $2.1 \times 10^{6} \mathrm{MPN} / \mathrm{g}$ TS) are higher than those reported in countries like the United States (faecal coliforms $2 \times 10^{7} \mathrm{MPN} / \mathrm{g}$ TS and Salmonella spp. $2.1 \mathrm{x}$ $10^{2} \mathrm{MPN} / \mathrm{g}$ total solids (TS)) and the United Kingdom where faecal coliform concentrations varying between $3.6 \times 10^{4}$ and $1.4 \times 10^{6} \mathrm{MPN} / \mathrm{g}$ TS and Salmonella spp. varying between $1.4 \times 10^{2}$ and up to $4.2 \times 10^{4} \mathrm{MPN} / \mathrm{g}$ TS are reported (Crewe, 1994; Jimenez et al., 2000; Jimenez et al., 2004; Reimers, 1986). Recently, Mendez et al. (2007) mentioned that in the central region of Veracruz State, raw physicochemical sludge from the food industry (bird slaughterhouse) contains extremely high concentrations of indicator and pathogenic bacteria ( $10^{9}$ and $10^{7} \mathrm{MPN} / \mathrm{g}$ TS, respectively). In addition, an important amount of sludge $(12 \mathrm{t} / \mathrm{d})$ is not treated or appropriately disposed of, being discharged to the sewer systems or landfills with little or no treatment at all. Literature regarding the development of technologies for sludge stabilisation with extremely high pathogen content is limited and a large amount of information deals with conventional stabilisation processes applied to sludge with 'typical' characteristics. Some of these technologies need to demonstrate their ability to significantly reduce those microorganisms that are

* To whom all correspondence should be addressed.

용 +52 - 272-7257056; fax: $+52-272-7257056$; e-mail: mmendez@itorizaba.edu.mx

Received 16 October 2008; accepted in revised form 10 December 2009. present in sludge generated in developing countries. Due to the simplicity of the operation and its low cost, one of the most efficient alternatives to treat this type of sludge is by means of alkaline stabilisation (Girovich, 1996). This process has high effectiveness in the inactivation of pathogenic microorganisms and it is capable to inactive up to 7 and 6 $\log$ of faecal coliforms and Salmonella spp., Mendez et al., (2002; 2004), but the effect of these biosolids when applied as organic fertilisers should be evaluated.

In according to Lira (1995), the biosolids produced via the alkaline method can be applied in farming or improvement of land due to its high content of organic matter and macronutrients such as nitrogen, phosphorus, potassium, calcium and magnesium and micronutrients such as iron, zinc, copper, manganese, boron, molybdenum and sodium, useful for plant cultivation. Also, Krasilnikov, (2002) and Díaz et al., (2004) reported the beneficial use of biosolids to promote the improvement of the partially degraded soils and also to increase in production potential of agricultural lands. The predominant type of soil in the Veracruz State is a vertisol which has a high content of organic matter $(6.93 \%)$ and nutrients. However, the agricultural activities, the use of chemical fertilisers and overgrazing are the major causes of soil degradation resulting in partial acidification of the land (Sánchez-Cólon, 2004). Considering vegetative species that may be fertilised with biosolids, chayote (Sechium edule) was selected as it is a vegetable species commonly consumed in Mexico, either eaten raw in salads or cooked, and it is exported to other countries. Thus, the aims of this study were to evaluate the effect of calcium oxide $(\mathrm{CaO})$ on the inactivation of high concentrations of faecal coliforms and Salmonella spp. present in physicochemical dewatered sludge, and to determine the impact of land-applied biosolids on the development and the production of Sechium edule. 


\section{Methods}

\section{Sludge and biosolids characteristics}

Raw physicochemical sludge containing $1.9 \% \pm 0.08$ TS was sampled from a $10 \ell / \mathrm{s}$ food-industry (bird slaughterhouse) wastewater treatment plant, located in Orizaba, Veracruz (México). A coagulation-flocculation process called advanced primary treatment (APT) or chemical enhanced primary treatment (CEPT) is employed to treat the wastewater. The sludge contains high levels of pathogenic bacteria. The counted densities of faecal coliforms and Salmonella spp. in the raw sludge (11 and 9 logs, respectively) were slightly higher than those reported by Mendez et al., 2007 ( 9 and $7 \operatorname{logs}$ ) in sludge produced in the south-east of Mexico.

\section{Stabilisation tests}

During this experimentation stage a hermetically sealed $4.5 \ell$ reactor was used, controlling the initial temperature at $20^{\circ} \mathrm{C}$. In order to obtain the required TS concentration, the sludge samples were thickened and dewatered by using a gravity method and a basket centrifuge, respectively. According to some previous studies (Atenodoro, 2007 and Mendez et al., 2008), the disinfectant power of alkaline materials like $\mathrm{CaO}$ or ammonia is reduced due to its dilution in the water contained in sludge. Thus, the necessary dose of $\mathrm{CaO}$ to achieve the reduction of pathogens can be reduced when the total solids concentration is higher. During this stage, doses of $0,10,20,30$ and $40 \% \mathrm{w} / \mathrm{w}$ of $\mathrm{CaO}$ were directly applied to the sludge with a concentration of total solids (TS) of $4 \%( \pm 0.03)$. The treatments with dewatered sludge $(8 \% \pm 0.04$ TS) were performed by applying of $\mathrm{CaO}$ in doses of $0,5,10,15$ and $20 \% \mathrm{w} / \mathrm{w}$. When the total solids concentration was $12 \%$, doses of $0,2,4,6$ and $8 \% \mathrm{w} / \mathrm{w} 12 \%$ TS were directly applied to the sludge. Following the method described by the process: Alkaline stabilisation of residual sludge in closed systems with optional ammonia recycling (Jimenez and Mendez, 2005), the samples and a control were homogenised for $2 \mathrm{~min}$, after which the $\mathrm{CaO}$ dose was applied and the speed of agitation was increased to $200 \mathrm{r} / \mathrm{min}$ during $2 \mathrm{~h}$. At the end of each treatment samples were taken for physicochemical and microbiological analyses. To evaluate the effect of the contact time, the recommended $\mathrm{CaO}$ dose was applied using times of $0,0.5,1,1.5$ and $2 \mathrm{~h}$ with TS concentrations of 4,8 and $12 \%$. The results of all stabilisation tests represent the average of 5 experiments. At the end of each experiment one factor and randomised block design (using the microorganism inactivation as a response variable), statistical analyses were carried out by using the NCSS software. With a strategy similar to the one used in the previous studies using the alkaline stabilisation process (Méndez et al., 2004). The kinetics parameter values were obtained by the Hom Kinetic Model using a non-linear least squares method. The kinetic model of the disinfection reactions has been described in a similar form to those for a chemical reaction. Presently, the predominant disinfection model is that proposed by Hom which is proposed as an alternative kinetic model to account for deviations from the ChickWatson Model commonly encountered in practice. The model evolved to (Pernitsky et al., 1995):

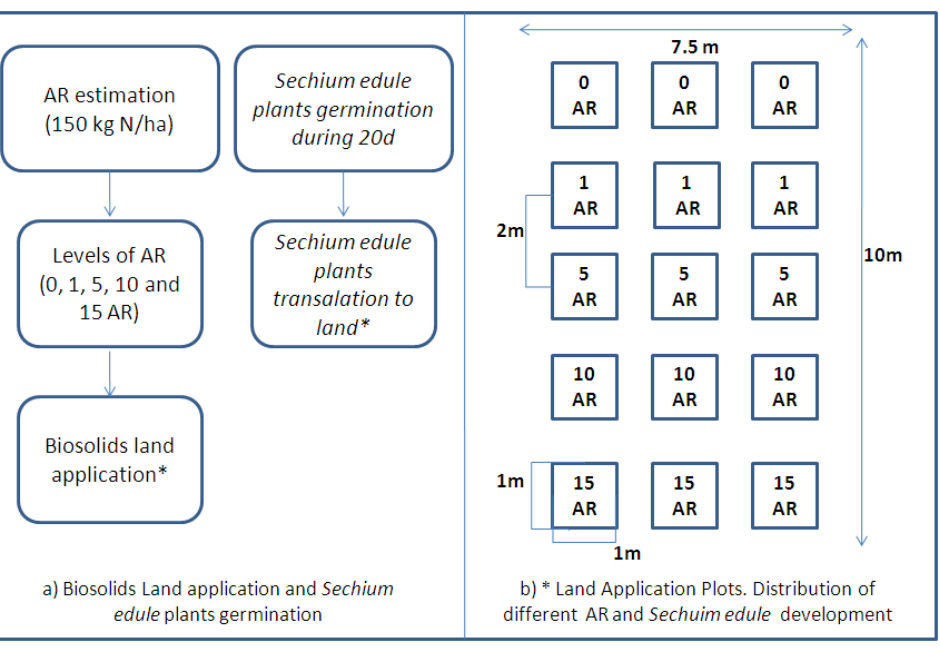

Figure 1

Experimental layout

TABLE 1

Soil characterisation

\begin{tabular}{|l|c|l|}
\hline Parameters & Unit & Method \\
\hline Fine grains & $\%$ & Size difference \\
\hline Heavy grains & $\%$ & Size difference \\
\hline Organic matter & -- & Potentiometer \\
\hline $\begin{array}{l}\text { Cation exchanged capacity } \\
\text { CEC) }\end{array}$ & $\mathrm{Cmol}^{+} \mathrm{kg}^{-1}$ & Colorimeter \\
\hline Texture & -- & Boyoucos method \\
\hline Apparent density & $\mathrm{g} / \mathrm{cc}$ & Volumetric method of Beaver \\
\hline Humidity & $\%$ & Gravimetric \\
\hline Retentive power of water & $\%$ & Gravimetric \\
\hline Phosphorus & $\mathrm{mg} / \mathrm{kg}$ & Colorimeter \\
\hline Total nitrogen & $\%$ & Kjeldahl Method \\
\hline Faecal coliforms & MPN/g TS & $9221 \mathrm{E}$ \\
\hline Salmonella spp. & MPN/g TS & $9221 \mathrm{~B}$ \\
\hline
\end{tabular}

$$
\operatorname{Ln} \frac{N}{N o}=-k * C^{n} t^{m}
$$

where:

No is the initial concentration of microorganisms

$N$ is the concentration of survival microorganisms at the time $t$

$k$ is the pseudo first-order reaction rate constant

$C$ is the disinfectant concentration

$n$ is a dilution coefficient which is an empirical factor

frequently assumed to be 1

$m$ is an empirical constant

\section{Biosolids application tests}

Vertisols were the soils chosen as substrate because they are the main soils found in agricultural lands in Veracruz, México. One experimental area was defined including $75 \mathrm{~m}^{2}$, where 10 plots of $1 \mathrm{~m} \mathrm{x} 1 \mathrm{~m}$ each were defined and distributed as shown in the experimental layout (Fig. 1). In order to identify the characteristics of studied soils, 10 samples were taken for physicochemical analyses according to the official regulation NOM-021-RECNAT-2001. The concentration of faecal coliforms and Salmonella spp. in the studied soils was evaluated over 3 different periods: 


\begin{tabular}{|c|c|c|c|c|}
\hline \multicolumn{5}{|c|}{$\begin{array}{r}\text { TABLE } 2 \\
\text { Physicochemical and microbiological }\end{array}$} \\
\hline Parameter & Units & Average value & $\begin{array}{l}\text { Standard } \\
\text { deviation }\end{array}$ & Method \\
\hline Total Solids & $\% \mathrm{w} / \mathrm{w}$ & 1.9 & 0.08 & 2540 B Standard Methods (APHA)* \\
\hline Volatile Solids & $\% \mathrm{w} / \mathrm{w}$ & 0.94 & 0.2 & $2540 \mathrm{E} *$ \\
\hline Fixed Solids & $\% \mathrm{w} / \mathrm{w}$ & 0.66 & 0.1 & $2540 \mathrm{E} *$ \\
\hline $\mathrm{pH}$ & -- & 7.42 & 0.08 & Potentiometer \\
\hline Ammoniacal nitrogen & $\mathrm{g} \mathrm{kg}^{-1} \mathrm{TS}$ & 4.46 & 0.29 & $4500-$ Norg B * \\
\hline Phosphorus & $\mathrm{g} \mathrm{kg}^{-1} \mathrm{TS}$ & 17.7 & 1.29 & $4500-$ Norg B * \\
\hline Faecal coliforms & MPN/g TS & $2.90 \times 10^{10}$ & $1.23 \times 10^{6}$ & $9221 \mathrm{E} *$ \\
\hline Salmonella spp. & $\mathrm{MPN} / \mathrm{g}$ TS & $1.59 \times 10^{8}$ & $1.3 \times 10^{8}$ & $9221 \mathrm{~B} *$ \\
\hline Helminth Ova & $\mathrm{HO} / \mathrm{g} \mathrm{TS}$ & 0 & 0 & NOM, 2002** \\
\hline \multicolumn{5}{|c|}{$(*$ APHA, 2008) $\quad(* *$ Mexican Official Regulation, NOM 2002) } \\
\hline
\end{tabular}

- Agricultural soil with no biosolids application

- After $2 \mathrm{~d}$ of biosolids application

- At the end of the crop cycle $(210 \mathrm{~d})$.

Parameters evaluated are shown in Table 1.

The agronomic rate (AR) was based on the nitrogen requirement for the Sechium edule (150 kg N/ha), the nitrogen concentration of the biosolids and heavy metal concentrations of the biosolids, according to the limits for land application proposed by the US EPA (1995). Once the agronomic rate was determined, 5 AR levels were established $(0,1,5,10$ and 15). The quantities of biosolids added to the land for each AR were $0.0,0.14,0.73,1.47$ and $2.2 \mathrm{~kg}$ of TS $/ \mathrm{m}^{2}$, respectively. Sechium edule plants were germinated during $20 \mathrm{~d}$, and then they were transplanted and kept in the experimental zone. During the study period $(210 \mathrm{~d})$, all the plants were irrigated daily with $17.49 \mathrm{~mm} / \mathrm{m}^{2}$. The height of the plant $(\mathrm{cm})$ was measured after first $90 \mathrm{~d}$. Generation of flowers occurred over a period of 91 to $120 \mathrm{~d}$; beyond this time, the production for each treatment (121 to $210 \mathrm{~d}$ ) was evaluated using the total weight and unitary weight and size.

\section{Results}

The raw sludge samples had to be thickened and dewatered to obtain the TS concentration necessary for each stabilisation test as the solids content of the sludge was low (Table 2). The chemical parameters showed levels of ammonia ( $44.6 \mathrm{~g} / \mathrm{kg}$ TS) and phosphorus (17.70 g/ kg) acceptable to produce biosolids for its later application. A unique characteristic of this type of sludge is the high concentration of pathogenic microorganisms which are above the permissible limits of the NOM-004-SEMARNAT-2002 regulation because of the nature of the sludge (bird slaughterhouse); concentrations of between $2.90 \times 10^{10}$ (faecal coliforms) and $1.23 \times 10^{8}$ (Salmonella $\mathrm{spp}$.) were quantified; this finding is in agreement with information given in reports on the sludge produced in a bird slaughterhouse (Salmonella are generally present on bird farms and concentrations of between $1.23 \times 10^{8}$ (Salmonella spp.) and $2.90 \times 10^{10}$ (faecal coliforms) are found). Note that the sludge did not contain helminth ova; this finding is in contrast with findings by Jimenez et al. (2004) who reported a high content of helminth ova in municipal sludge studied in places like Mexico City.

The heavy metal content of this sludge was identified as being low, similar in nature to some municipal sludge in Mexico; this allowed maximum permissible application in terms of the official Mexican regulation limits (Table 3). Jimenez et

\begin{tabular}{|l|c|c|l|}
\hline \multicolumn{4}{|c|}{ TABLE 3 } \\
\hline \multicolumn{4}{|c|}{ Heavy metals in raw sludge } \\
\hline Metal (mg/kg) & Detection limit & Results & Reference \\
\hline Arsenic & $0.1 \mathrm{mg} / \mathrm{kg}$ & $<$ DL & EPA 7061A \\
\hline Cadmium & $1.0 \mathrm{mg} / \mathrm{kg}$ & $<$ DL & EPA 7130 \\
\hline Copper & $2.0 \mathrm{mg} / \mathrm{kg}$ & $<$ DL & EPA 7210 \\
\hline Chromium & $2.0 \mathrm{mg} / \mathrm{kg}$ & $<$ DL & EPA 7190 \\
\hline Mercury & $0.01 \mathrm{mg} / \mathrm{kg}$ & $<$ DL & EPA 7471A \\
\hline Nickel & $2.0 \mathrm{mg} / \mathrm{kg}$ & $<\mathrm{DL}$ & EPA 7520 \\
\hline Lead & $2.0 \mathrm{mg} / \mathrm{kg}$ & $<\mathrm{DL}$ & EPA 7420 \\
\hline Zinc & $0.005 \mathrm{mg} / \mathrm{kg}$ & $<\mathrm{DL}$ & EPA 7950 \\
\hline DL Detection level & \\
\hline
\end{tabular}

al. (2004) previously reported the low concentration of metals in sludges produced in Mexico. Because these concentrations are lower than the detection limits, they do not influence the determination of the agronomic application rates.

During the stabilisation tests, the selected recommended $\mathrm{CaO}$ doses were those required to reduce groups of identified bacteria (faecal coliforms and Salmonella spp.) up to levels which met with Class A biosolids limits. Thus, the recommended doses for the studied TS concentrations were obtained - doses of 20,10 and $8 \% \mathrm{CaO} \mathrm{m} / \mathrm{m}$ were necessary to inactivate the bacteria groups in sludges with 4, 8 and 12\% ST, respectively (Figs. 2 and 3, next page). These stabilisation conditions were necessary to meet Class A biosolids limits. In both cases, it should be noted that in sludges with higher TS concentrations of, the $\mathrm{CaO}$ doses were reduced.

In a $2^{\text {nd }}$ trial, the contact time for each concentration of TS was decided in terms of its respective recommended dose. From experiments with different contact times it is observed, in Figs. 4 and 5 (next page), that similar times are needed to inactivate Salmonella spp. and faecal coliforms (90 min). Thus, as recommended for $\mathrm{CaO}$ stabilisation (US EPA, 1994), at least $2 \mathrm{~h}$ are needed for alkaline disinfection of sludges. Based on the contact time obtained, the alkaline stabilisation can be considered a fast process when compared with other methods of stabilisation such as the thermophilic anaerobic digestion, which generally requires an HRT of up to $20 \mathrm{~d}$ to reach a similar level of stabilisation (Young-Chae et al., 2004).

The inactivation of faecal coliforms and Salmonella spp. at different $\mathrm{CaO}$ concentrations ( $\mathrm{C}$ from Eq.(1) and $2 \mathrm{~h}$ of contact time was described by the modified Hom Model. The resultant equation is: 


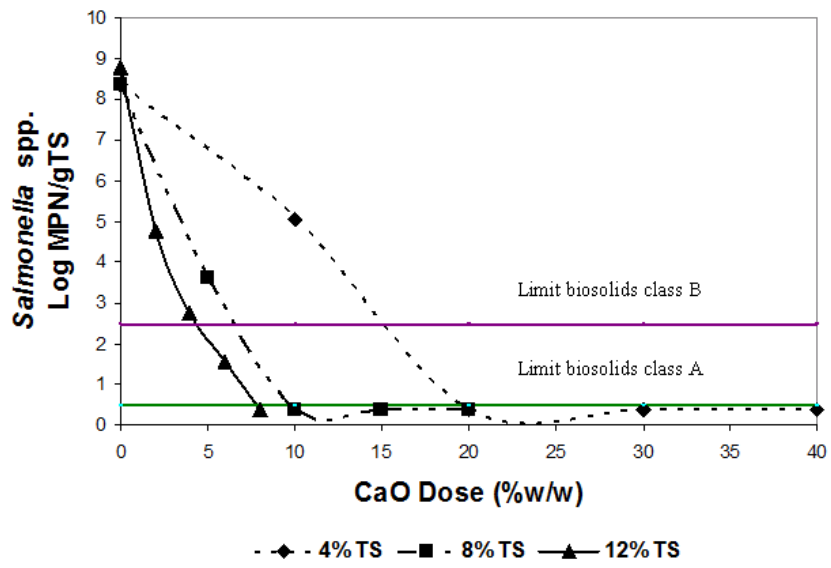

Figure 2

Removal of faecal coliforms in treated sludge with different $\mathrm{CaO}$ doses at different TS concentrations

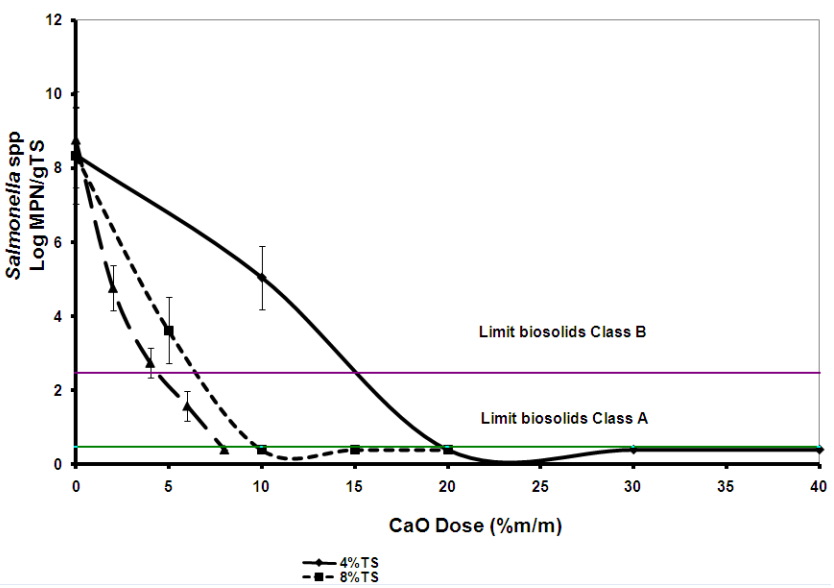

Figure 3

Removal of Salmonella spp. in treated sludge with different $\mathrm{CaO}$ doses at different TS concentrations

$$
\operatorname{Ln} \frac{N}{N o}=-k * D^{n}
$$

where:

$D$ is $\mathrm{CaO}$ dose $(\mathrm{g} / \ell)$

$k^{*}$ is a constant associating $k$ and the time $t^{m}$

Table 4 shows the kinetic parameters for Hom's Modified Model, where the effect of the $\mathrm{CaO}$ doses is evaluated for each concentration of TS. The rate $\left(k^{*}\right)$ of inactivation is faster for Salmonella spp. than for coliforms because this last group is 1 and 2 log higher than Salmonella spp. in all the total solids concentrations evaluated; values of the rate constant of inactivation for the faecal coliforms are higher than those obtained for Salmonella spp. Low dilution coefficient values $(n)$ were observed in a range of 0.45 to 0.62 for faecal coliforms and 0.32 to 0.49 for Salmonella spp. attributable to the interference that determines the solids content in the sludge. The $\mathrm{R}^{2}$ values ranged from 0.90 up to 0.97 , which is high enough to give the model practical value for forecasting of pathogen microorganism inactivation.

To describe the inactivation of faecal coliforms and Salmonella spp. at different contact times the Hom Model (Eq.(1)) was adapted replacing the $k$ parameter and the $\mathrm{CaO}$ dose by $k^{* *}$ :

$$
\operatorname{Ln} \frac{N}{N o}=-k * * t^{m}
$$

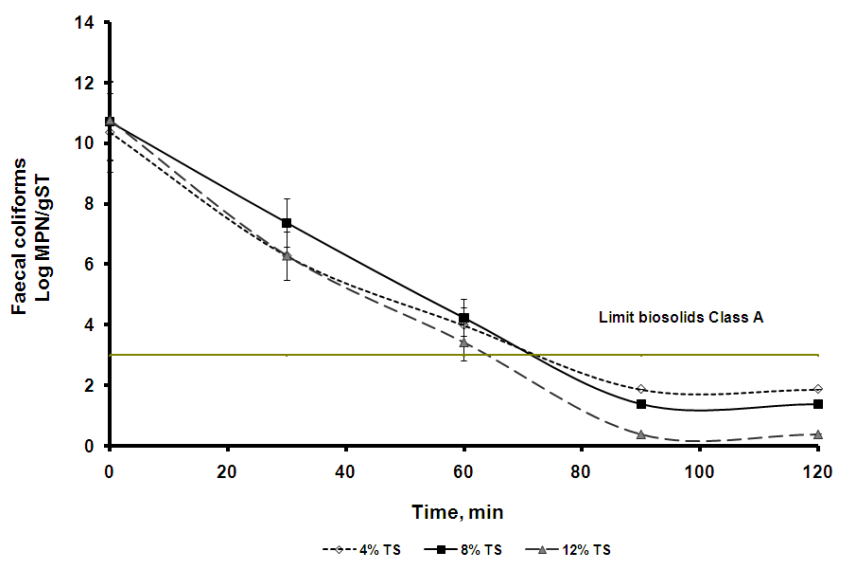

Figure 4

Removal of faecal coliforms in treated sludge with different contact times at different concentrations of TS

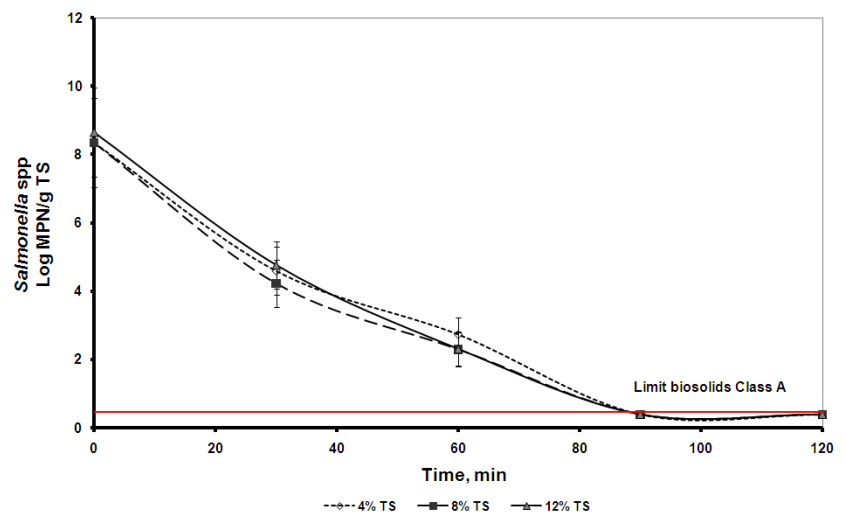

Figure 5

Removal of Salmonella ssp. in treated sludge with different contact times at different TS concentrations

where:

$k^{* *}$ : is a constant associating $k$ and the $\mathrm{CaO}$ dose $\mathrm{D}^{n}$

Table 5 shows the kinetic parameters for the contact time in the 3 concentrations of total solids. In the same way, the higher velocity of inactivation of Salmonella spp. and low values of Hom's empiric constant (ranging between 0.42 and 0.68 ) are observed, which indicates deviations from the first order kinetic; again high values ( 0.93 to 0.96 ) of the $\mathrm{R}^{2}$ coefficient were obtained. The higher efficiencies obtained in the stabilisation process can be related to the use of a closed system, as the ammonia produced in the alkaline process remains in the reactor during the stabilisation tests and this gas has a high disinfectant power according to Jimenez and Mendez (2005) and Mendez et al., (2004; 2002).

\begin{tabular}{|c|l|c|c|c|}
\hline \multicolumn{5}{|c|}{$\begin{array}{c}\text { TABLE 4 } \\
\text { Kinetic parameters for the Hom Model for different } \\
\text { doses and concentrations of TS }\end{array}$} \\
\hline \multirow{2}{*}{$\%$ TS } & Microorganisms & $\boldsymbol{k}^{*}$ & $\boldsymbol{n}$ & $\boldsymbol{R}^{\mathbf{2}}$ \\
\hline \multirow{2}{*}{} & Faecal coliforms & 2.52 & 0.45 & 0.9 \\
\cline { 2 - 5 } & Salmonella spp. & 2.69 & 0.35 & 0.92 \\
\hline \multirow{2}{*}{8} & Faecal coliforms & 2.23 & 0.52 & 0.93 \\
\cline { 2 - 5 } & Salmonella spp. & 3.13 & 0.32 & 0.93 \\
\hline \multirow{2}{*}{12} & Faecal coliforms & 1.99 & 0.62 & 0.97 \\
\cline { 2 - 5 } & Salmonella spp. & 2.28 & 0.49 & 0.95 \\
\hline
\end{tabular}




\begin{tabular}{|l|l|c|c|c|}
\hline \multicolumn{5}{|c|}{$\begin{array}{c}\text { TABLE 5 } \\
\text { Kinetic parameters for the Hom Model for different } \\
\text { contact times and concentrations of TS }\end{array}$} \\
\hline \multirow{2}{*}{ TS } & Microorganisms & $\mathbf{k}^{* *}$ & $\mathbf{m}$ & $\boldsymbol{R}^{\mathbf{2}}$ \\
\hline \multirow{2}{*}{} & Faecal coliforms & 0.47 & 0.64 & 0.96 \\
\cline { 2 - 5 } & Salmonella spp. & 2.05 & 0.51 & 0.96 \\
\hline \multirow{2}{*}{8} & Faecal coliforms & 0.4 & 0.68 & 0.96 \\
\cline { 2 - 5 } & Salmonella spp. & 1.07 & 0.42 & 0.93 \\
\hline \multirow{2}{*}{12} & Faecal coliforms & 0.4 & 0.62 & 0.96 \\
\cline { 2 - 5 } & Salmonella spp. & 0.82 & 0.49 & 0.94 \\
\hline
\end{tabular}

At the end of the stabilisation tests, statistical analyses were carried out in both of the cases (different $\mathrm{CaO}$ doses and contact times). The Fo values from ANOVA analyses are shown in Table 6. Values between 153 and 899 were obtained which are much higher than $\mathrm{F}_{0.05,4,16}=3.01(\alpha=0.05)$ values. In consequence, it is possible to confirm that the $\mathrm{CaO}$ doses and the contact time have a significant effect on the inactivation of both of the studied bacteria groups.

The results obtained in the description of the soil are shown in Table 7. As observed, the average $\mathrm{pH}$ value (6.87) was neutral. According to Lira, (1995) it is advisable to maintain the $\mathrm{pH}$ of agricultural soils where biosolids are being applied in the optimum range for the food crop growth at between 5.7 and 7.0 to avoid biosolids-supplemented metals. The quantified organic matter was considered high (6.93\%; Cooperband, 2002 and NOM-021-RECNAT-2001) and it is common in agricultural soils with higher water-holding capacity. The main nutrients represented by the total nitrogen $(0.2 \%)$ along with phosphorus $(2.06 \mathrm{mg} / \mathrm{kg})$, are present in high and low concentrations, respectively, according to the criteria established by NOM-021-RECNAT-2001. Based on these characteristics, the agricultural soils are appropriate to receive the alkaline stabilised biosolids.

On the other hand, minimum bacterial concentration densities were $(<3 \mathrm{MPN} / \mathrm{g}$ TS) observed in the samples of all 10 soils analysed; this effect was expected because, according to Garrido et al. (2005), due to contamination, fertilisation, competitions existing among microorganisms and farming operations, most of the microorganisms that are disseminated throughout the soil do not form spores, so they remain in the soil for only a short period of time, the soil being an unfavourable medium for most pathogenic species.

The growth rate of Sechium edule observed is shown in Tables 8 and 9 (next page). The treatment with 0 AR was used to compare with the other treatments because the literature regarding the cultivation of chayote is mainly focused on the weight of the plant $(\mathrm{kg} / 100 \mathrm{~d})$. However, in this case the most important control variable was the total production achieved. Thus, the application of the biosolids increased the growth of the species. In fact, the growth rate for treatments with 5 and $10 \mathrm{AR}$ was higher compared to the remaining treatments due to the effect of the nutrients contained in the applied biosolids. Although the Sechium edule plants require $33 \%$ of mineralised organic nitrogen plus nitrogen available $\left(\mathrm{N}-\mathrm{NH}_{4}\right)$ for their optimum growth, 33\% for the flowering and 33\% for the crop production (Lira, 1995), under our experimental conditions, only one biosolids application and incorporation in the first $45 \mathrm{~cm}$ of agricultural soil was made (1 month before seeding the plants) to avoid negatively affecting the chayote adaptation, growth and production cycle and also to avoid anaerobic conditions in the upper soil layers.

To evaluate the effect of the biosolids application the main variable was the average production of Sechium edule during

\begin{tabular}{|l|c|c|c|c|c|c|}
\hline \multicolumn{7}{|c|}{ TABLE $\mathbf{6}$} \\
\hline \multirow{2}{*}{$\begin{array}{l}\text { Micro- } \\
\text { organisms }\end{array}$} & \multicolumn{7}{|c|}{ Faecal coliforms } & \multicolumn{4}{c|}{ Salmonella spp. } \\
\cline { 2 - 7 } & $\mathbf{4 \%}$ TS & $\mathbf{8 \%}$ TS & $\mathbf{1 2} \%$ TS & $\mathbf{4 \%}$ TS & $\mathbf{8 \%}$ TS & $\mathbf{1 2 \%}$ TS \\
\hline Doses of CaO & 312.54 & 898.91 & 689.67 & 312.54 & 898.91 & 689.67 \\
\hline Contac time & 523.9 & 650 & 670 & 173.73 & 264 & 153 \\
\hline$* \alpha=0.05 ; \quad F_{0.05,4,16}=3.01$ \\
\hline
\end{tabular}

\begin{tabular}{|c|c|c|c|c|c|}
\hline \multicolumn{6}{|c|}{$\begin{array}{c}\text { TABLE } 7 \\
\text { Soil characteristics }\end{array}$} \\
\hline Parameters & Unit & $\begin{array}{l}\text { Obtained } \\
\text { value }\end{array}$ & classification & $\begin{array}{l}\text { Reference } \\
\text { value }\end{array}$ & Reference \\
\hline Fines grains & $\%$ & 45.58 & \multirow{2}{*}{ Mix structure } & \multirow{2}{*}{ W.R. } & \multirow{2}{*}{ Lira (1995) } \\
\hline Heavy grains & $\%$ & 54.52 & & & \\
\hline Texture & S-M-C & $\mathrm{AM}$ & Sand - crumb & & NOM-021-RECNAT-2001 \\
\hline Apparent density & $\mathrm{g} / \mathrm{cm}^{3}$ & 0.85 & Oraganic soil & $<1$ & NOM-021-RECNAT-2001 \\
\hline $\mathrm{pH}$ & & 6.87 & Neutral & $6.70-7.40$ & NOM-021-RECNAT-2001 \\
\hline Organic matter $(\mathrm{OM})$ & $\%$ & 6.93 & High & $5.1-14.00$ & $\begin{array}{l}\text { Cooperband, (2002) and } \\
\text { NOM-021-RECNAT-2001 }\end{array}$ \\
\hline Cation exchange capacity (CEC) & $\mathrm{Cmol}^{+} \mathrm{K}^{-1}$ & N.D. & Low & $<15$ & NOM-021-RECNAT-2001 \\
\hline Humidity & $\%$ & 92.7 & W.R. & W.R. & NOM-021-RECNAT-2001 \\
\hline Water retention capacity & $\%$ & 67.93 & W.R. & W.R. & NOM-021-RECNAT-2001 \\
\hline Phosphorus & ppm & 2.06 & Low & $<5.5$ & NOM-021-RECNAT-2001 \\
\hline Total nitrogen & $\%$ & 0.2 & High & $<0.032$ & NOM-021-RECNAT-2001 \\
\hline
\end{tabular}




\begin{tabular}{|c|c|c|c|c|c|c|c|c|}
\hline \multicolumn{7}{|c|}{ TABLE 8 } & \\
\hline AR & \multicolumn{7}{|c|}{ Days } & $\begin{array}{c}\Delta \\
\text { Growth }\end{array}$ \\
\cline { 2 - 10 } & $\mathbf{0}$ & $\mathbf{1 5}$ & $\mathbf{3 0}$ & $\mathbf{4 5}$ & $\mathbf{6 0}$ & $\mathbf{7 5}$ & $\mathbf{9 0}$ & $\begin{array}{c}\mathbf{( c m /} \\
\mathbf{9 0} \mathbf{d})\end{array}$ \\
\hline 0 & 70 & 88 & 102 & 133 & 174 & 225 & 257 & 186 \\
\hline 1 & 29 & 48 & 58 & 89 & 130 & 219 & 252 & 222 \\
\hline 5 & 84 & 102 & 113 & 144 & 185 & 237 & 270 & 187 \\
\hline 10 & 38 & 64 & 81 & 118 & 159 & 220 & 253 & 215 \\
\hline 15 & 38 & 56 & 37 & 54 & 76 & 103 & 136 & 98 \\
\hline
\end{tabular}

TABLE 9

Daily average crop growth rate Daily average growth (cm)

\begin{tabular}{|c|c|c|c|c|}
\hline $0 \mathrm{AR}$ & $1 \mathrm{AR}$ & $5 \mathrm{AR}$ & $10 \mathrm{AR}$ & $15 \mathrm{AR}$ \\
\hline 1.36 & 1.37 & 1.38 & 1.63 & 0.73 \\
\hline
\end{tabular}

TABLE 10

Total production in $90 \mathrm{~d}$ and physical characteristics of the product

\begin{tabular}{|l|c|c|c|c|c|}
\hline Treatment & \multirow{2}{*}{$\begin{array}{c}\text { Biosolids } \\
\text { doses }\end{array}$} & \multirow{2}{*}{$\begin{array}{c}\text { Yield Crop } \\
\text { (kg/ha) }\end{array}$} & \multicolumn{2}{|c|}{ Physical qualities of the cultivation } \\
\cline { 4 - 6 } & (dry ton/ha) & & $\begin{array}{c}\text { kg of fruit/ } \\
\text { treatment }\end{array}$ & Length & Width \\
\hline 0 AR & 0.0 & 19965 & 7.99 & 8.44 & 6.24 \\
\hline 1 AR & 1.4 & 125285 & 50.11 & 9.17 & 6.84 \\
\hline 5 AR & 7.3 & 177022.5 & 70.81 & 9.41 & 6.86 \\
\hline 10 AR & 14.7 & 106525 & 42.61 & 9.13 & 8.69 \\
\hline 15 AR & 22.0 & 31617.5 & 12.647 & 9.34 & 7.09 \\
\hline
\end{tabular}

\begin{tabular}{|l|l|}
\hline \multicolumn{2}{|c|}{$\begin{array}{c}\text { TABLE 11 } \\
\text { Comparative production }\end{array}$} \\
\hline \multirow{2}{*}{ Normal cultivation } & Production in $\mathbf{~ k g} / \mathbf{h a}$ \\
\hline & Harvest time in 90 days \\
\cline { 2 - 2 } & $92,085^{*}$ \\
\hline Cultivation with biosolids (5AR) & Harvest time in 90 days \\
\cline { 2 - 2 } & 177000 \\
\hline *Lira 1995 \\
\hline
\end{tabular}

each trial. Table 10 presents a higher production figure (70.81 $\mathrm{kg}$ of fruit) when $5 \mathrm{AR}$ of biosolids was applied. The treatment without biosolids (0 AR) produced a lower production probably as a result of the lower concentration of nitrogen and phosphorus present in the soils. The type of experimental soil and the farming operations in the experimental plots agree with those commonly used by chayote growers in the Veracruz State, Mexico. Also, when the application of biosolids is repeated in a bigger agricultural soil sample with similar characteristics the results will be similar to those obtained in this study. Thus, the yield obtained in the experimental lots was directly extrapolated to the yield measured in international measurement units $(\mathrm{kg} / \mathrm{Ha})$. Table 11 shows the attainable production achieved using the different AR treatments with $5 \mathrm{AR}$ being the treatment with higher potential production (177 $000 \mathrm{~kg} / \mathrm{ha})$, which could be up to $92 \%$ higher than that reported by Lira (1995) as a conventional production figure $(92.085 \mathrm{~kg} / \mathrm{ha})$. Necessarily, results obtained on a larger scale would need to be demonstrated.

In Fig. 6 the average monthly production is shown - it was observed that for $5 \mathrm{AR}$ the production started earlier than the remaining treatments and the harvest presented Gaussian type growth for the treatments with 1,5 and $10 \mathrm{AR}$. In the treatment with $15 \mathrm{AR}$ this kind of evolution was not more evident and its production was low and late. This effect can be due to the direct contact of the biosolids with the root of the chayote which caused hypernutrient stress that the plants cannot tolerate. Also, other important factor is the amount of applied biosolids ( 22 dry ton/ha) which can produce oxygen depletion in the upper soils layer reducing the development of the Sechium edule plants.

\section{Conclusions}

The obtained results show that the $\mathrm{CaO}$ has an effective disinfectant property, which is able to reduce extremely high levels of pathogenic microorganisms (faecal coliforms and Salmonella spp.). The $\mathrm{CaO}$ requirements were reduced when the concentration of TS increased. This is probably due to the fact that the $\mathrm{CaO}$ is mainly consumed in the inactivation of microorganisms and not in the formation of $\mathrm{Ca}(\mathrm{OH})_{2}$ A concentration of $8 \%$ TS is recommended since the $\mathrm{CaO}$ requirements are low compared to $4 \% \mathrm{TS}$ and presents practical advantages related to the physical mix compared to the $12 \%$ TS.

Results suggest that $\mathrm{CaO}$ can inactivate microorganisms in a relatively short contact time $(90 \mathrm{~min})$. A contact time of at least $2 \mathrm{~h}$ is recommended.

The kinetics parameters determined in this study are use-ful for the design, operation and control of an alkaline process using closed systems for stabilisation of sludge with varying concentrations of total solids. Nevertheless, they were obtained from experimental tests carried out in food processing sludge; which had not concentrations of helminth ova. Different types of sludge, particularly those from

Figure 6

Average monthly productions

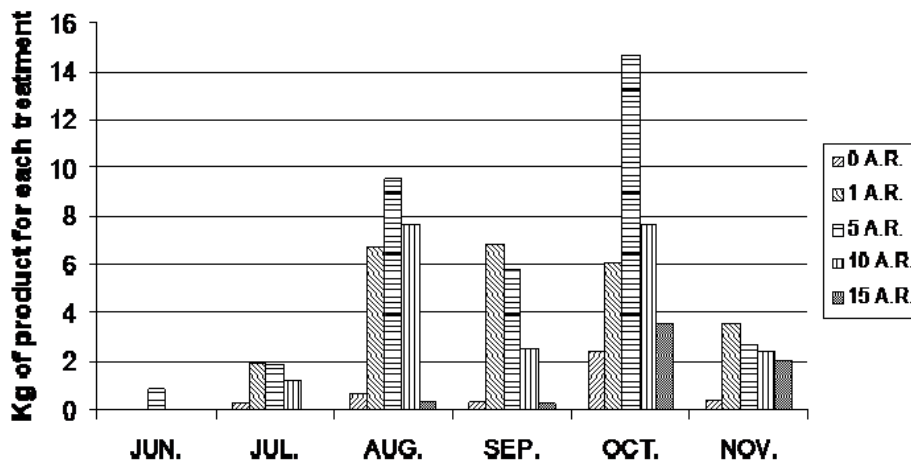


municipal wastewater need to be studied.

According to the obtained results it was demonstrated that the treatment of vertisols with biosolids (5 AR) can increase the productivity of the studied agricultural soils. Since the maximum production of chayote after a period of $90 \mathrm{~d}$ was $70.81 \mathrm{~kg}$ when using $5 \mathrm{AR}$, results suggest that biosolids can incorporate essential nutrients to soils which are used by chayote (Sechium edule) plants for their growth and development. Besides that, the times for production and harvest were reduced when comparing the results obtained for the control (0 AR).

The impact of quicklime-treated biosolids applied to vertisols proved the potential for reusing biosolids to improve the fertility of this type of soils during the productive cycle of Sechium edule and the disposal problematic of this sludge can be resolved.

\section{References}

ATENODORO A J (2007) Inactivación bacteriológica en lodos residuales deshidratados mediante el proceso de estabilización alcalina con óxido de calcio y recirculación de amoniaco. Tesis de Maestría. Programa en Ingeniería Química. Instituto Tecnológico de Orizaba. Mexico. 127 pp.

COOPERBAND L (2002) Building Soil Organic Matter with Organic Amendments. Center for Integrated Agricultural Systems. University of Wisconsin-Madison. USA.

CREWE W (1994) Transmission of Taenia saginata in Britain. Ann. Trop. Med. Parasitol. 78 249-251.

DÍAZ-AVELAR J, BARRIOS JA and JIMENEZ B (2004) Effect of the application of acid treated biosolids on marigold (Tagetes erecta) development. Water Sci. Technol. 50 (9) 33-40.

GARRIDO S, MARTIN DEL CAMPO G, ESTELLER MV, VACA R and LUGO J (2005) Heavy metals in soil treated with sewage sludge composting, their effect on yield and uptake of broad bean seeds (Vicia faba L.). Water Air Soil Pollut. 166 303-319.

GIROVICH M (1996) Biosolids Treatment and Management Processes for Beneficial Use. Marcel Dekker, Inc., USA.

JIMENEZ B and MENDEZ JM (2005) Alkaline stabilisation of residual sludge in closed systems with optional ammonia recycling. World Intellectual Property Organization. Patent WO 2005/051853 A1.

JIMENEZ B, BARRIOS JA, MENDEZ JM and DIAZ J (2004) Sustainable sludge management in developing countries. Water Sci. Technol. 49 (10) 251-258.

JIMENEZ B, BARRIOS JA and MAYA C (2000) Class B biosolids production from wastewater sludge with high pathogenic content generated in an advanced primary treatment. Water Sci. Technol. 42 (9) $103-110$.

KRASILNIKO VP (2002) An experience in correlating world reference base for soil resources with national soil classifications. Trans. Proc. 17 th World Congress of Soil Science. 14-21 August 2002, Bangkok, Thailand. 2031 1-10.
LIRA R (1995) Estudios taxonómicos en el género "Sechium edule" P.Br. (Cucurbitacea). Ph. D. Thesis. Facultad de Ciencias, Universidad Nacional Autónoma de México. 267 pp.

MENDEZ JM, GONZALEZ C, ALVARADO-LASSMAN A, ALVARADO-KINELL G and MARTINEZ-DELGADILLO S (2008) Fecal bacteria survival in ammonia-treated wastewater dewatered sludge. Rev. Mex. Ing. Quím. 7 (3) 229-235.

MENDEZ JM, CORTE J, NARVAEZ IE and ALVARADO-LASSMAN A (2007) Improvement of the sludge mesophilic anaerobic digestion via thermic inactivation of indicator and pathogen bacteria. Proc. $4^{\text {th }}$ IWA Leading Edge Conference and Exhibition on Water and Wastewater Technology. 3-6 June 2007, Singapore. 3 1-8.

MENDEZ JM, JIMENEZ B and MAYA C (2004) Disinfection kinetics of pathogens in physicochemical sludge treated with ammonia. Water Sci. Technol. 50 (9) 67-74.

MENDEZ JM, JIMENEZ BE and BARRIOS JA (2002) Improved alkaline stabilization of municipal wastewater sludge. Water Sci. Technol. 46 (10) 139-146.

NOM-004-SEMARNAT-2002. Protección ambiental - Lodos y biosólidos.-Especificaciones y límites máximos permisibles de contaminantes para su aprovechamiento y disposición final. Diario Oficial de la Federación. Mexico.

NOM-021-RECNAT-2001. Norma que establece las especificaciones de fertilidad, salinidad y clasificación de suelos. Estudio, muestreo y análisis. México. Diario Oficial de la Federación. Mexico.

OBERHASTER G (1991) South African practice in land disposal of sludge, including legislation and health aspects. Water Sci. Technol. 15 151-155.

ORTEGA SRD, CASTILLO CJ, COLIN CA, SALAZAR MSA (2003) Genotoxicidad del lixiviado de lodos residuales. Proc. VIII Environmental Science National Congress. Mexico. 1-8.

PERNITSKY DJ, GORDON RF and HUCK PM (1995) Disinfection kinetics of heterotrophic plate count bacteria in biologically treated potable water. Water Res. 29 (5) 1235-1241.

REIMERS RS, McDONELL D and LITTLE M (1986) Chemical inactivation of pathogens in municipal sludge. In: CA Sober (ed.) Control of Sludge Pathogens. Water Pollution Control Federation, Washington, DC USA. 1-23.

SÁNCHEZ-COLÓN S (2004) Evaluation of human-induced soil degradation in Mexico. In: R Francaviglia (ed.) Agricultural Impacts on Soil Erosion and Soil Biodiversity: Developing Indicators for Policy Analysis, Proc. from an OECD Expert Meeting, Rome, Italy, March 2003. Istituto Sperimentale per la Nutrizione delle Piante (ISNP), Rome, Italy. 293-300.

STANDARD METHODS (1998) Standard Methods for the Examination of Water and Wastewater $\left(20^{\text {th }}\right.$ edn.) APHA, AWWA and WEF, Washington, DC, USA.

US EPA (1994) A Plain English Guide to the EPA, Part 503 Biosolids Rule. US EPA/832/R-93-003.

US EPA (1995) Process Design Manual, Land Application of Sewage Sludge and Domestic Septage. Office of Research and Development. US EPA/625/K-95/.

YOUNG-CHAE S, SANG-JO K and JUNG-HUI W (2004) Mesophilic and thermophilic temperature co-phase anaerobic digestion compared with single-stage mesophilic and thermophilic digestion of sewage sludge. Water Res. 38 1653-1662. 
